\title{
Are human herpes viruses associated with autoimmune thyroid disease?
}

\author{
Noura AL-Zarzour and Fawza Monem \\ Faculty of Pharmacy, Damascus University, Damascus, Syria
}

\begin{abstract}
Introduction: Autoimmune diseases are complex diseases with genetic, endogenous and environmental etiologies. Viral infections have been postulated as one of the factors that may be the trigger of autoimmune diseases.

Methodology: Thyroid peroxidase (TPO) and thyroglobulin (TG) antibodies were measured before thyroidectomy in 100 subjects by chemiluminescence method, 50 of whom were autoimmune thyroid diseases (AITD) patients and 50 of whom were multinodular goiter (MNG) patients used as a control group. Fresh thyroid samples were collected from all 100 subjects after thyroidectomy to investigate the DNAs of herpes simplex viruses types 1 and 2 (HSV-1, HSV-2), Varicella Zoster virus (VZV), Epstein-Barr virus (EBV), Cytomegalovirus (CMV) and human herpes virus type 6 (HHV-6) by PCR.

Results: The DNA of HSV-1, HSV-2, VZV, EBV, CMV and HHV-6 were detected in neither the patient group nor in the control group. The mean values of anti-TPO and anti-TG antibodies ranged within $9.5-2000 \mathrm{units} / \mathrm{ml}(527.8 \pm 617.4)$ and $108-5000 \mathrm{units} / \mathrm{ml}(1458.2 \pm 1774.1)$ in the AITD patients group, respectively. A statistically significant difference of the mean level of anti-TPO and anti-TG antibodies among the two groups was found ( $\mathrm{p}$ value $<0.05$ ).

Conclusions: The possible role of human herpes viruses in the pathogenesis of AITD is not supported by our study; hence our raised question stays open for more investigation on more patients and in different parts of the country using different sizes and sites of biopsies.
\end{abstract}

Key words: autoimmune thyroid diseases; herpes viruses in thyroid disease; thyroid autoantibodies; thyroid biopsies

J Infect Dev Ctries 2011; 5(12):890-892.

(Received 29 November 2010 - Accepted 14 May 2011)

Copyright (C) 2011 Al-Zarzour and Monem. This is an open-access article distributed under the Creative Commons Attribution License, which permits unrestricted use, distribution, and reproduction in any medium, provided the original work is properly cited.

\section{Introduction}

Autoimmune thyroid diseases (AITD) are the archetype of organ-specific autoimmune disorders [1] which are seen mostly in women between 30 - to 50 years old. Susceptibility to the diseases is determined by a combination of genetic, environmental, and endogenous factors [2].

AITD include Grave's disease, Hashimoto's thyroiditis, atrophic autoimmune hypothyroidism, postpartum thyroiditis, and silent thyroiditis $[3,4]$. Antibodies to thyroid peroxidase (TPO) and thyroglobulin (TG) are the main markers of AITD $[3,5]$. They can be measured in serum by various methods including the chemiluminescence method [6] .

Herpesviridae represent a large family of viruses that are pathogenic for many vertebrates. Several members of this family cause lifelong infections that are characterized by periods of quiescence followed by reactivation [7] due to psychological stress, sun exposure, and onset of menses [8].

Although many studies suggest that herpes virus infections are involved in a variety of autoimmune diseases [9], very little is known about their role as one of the triggering factors of AITD; therefore, our study was conducted to investigate this possible association in Syrian patients.

\section{Methodology \\ Patients and samples}

One hundred subjects who were previously diagnosed according to their clinical and laboratory findings were recruited for the study and divided into two groups. The first group consisted of 50 patients with AITD (age range $37.1 \pm 10.6$ years) while the second group of 50 patients (age range $42.4 \pm 11.4$ ) with multinodular goiter (MNG) acted as a control group. Informed consent was obtained upon recruitment. Fresh thyroid biopsies were obtained from all 100 patients, collected in sterile cryotubes (Greiner Bio-One, Mosonmagyaróvár, Hungary) and stored at $-80^{\circ} \mathrm{C}$ for further investigation.

\section{Tissues preparation and DNA isolation}

Freshly frozen biopsies $(5-10 \mathrm{mg})$ were placed into micro centrifuge tubes and $200 \mu \mathrm{l}$ of cell lysis 
solution (Gentra, Plymouth, MI, USA) was added. DNA was isolated using the QIAamp blood mini kit (Qiagen, Valencia, CA, USA) according to the manufacturer's instructions after modifying the elution buffer volume to $50 \mu 1$.

To assess the quality (adequacy) of isolated DNA, we performed two procedures: (1) Using a NanoDrop ND-1000 UV-Vis Spectrophotometer (NanoDrop Technologies Inc, Wilmington, DE, USA), the quality of isolated DNA was determined by the ratio of $260 / 280 \mathrm{~nm}$, and the quantity by absorbance at $260 \mathrm{~nm}$; (2) A 769-bp fragment of cellular beta-globin gene was amplified for each sample by real-time PCR using the FastStart DNA Master Hybridization Probes kit (Roche Diagnostics, Penzberg, Germany) on a LightCycler Instrument (Roche Applied Science, Penzberg, Germany) according to the laboratory developed method. The reaction mix was composed of $0.5 \mu \mathrm{M}$ primers (forward primer: TAAgCCAgTgCCAgAAgAgCC; reverse primer: ATCATTCgTCTgTTTCCCATTCTAAAC [10]; TIB Molbiol, Berlin, Germany), $0.2 \mu \mathrm{M}$ probes (FLprobe: CCCTTggACCCAgAggTTCTTTgAgTCCTFL; LC-Red-Probe: LC-Red640TggggATCTgTCCACTCCTgATgCTgTTATg-p

[11]; TIB Molbiol, Berlin, Germany), and $3 \mathrm{mM}$ $\mathrm{MgCl}_{2}$ in a final reaction volume of $10 \mu \mathrm{l}$. Cycling conditions were initiated by an activation step at $95^{\circ} \mathrm{C}$ for 10 minutes, followed by 45 cycles of denaturation at $95^{\circ} \mathrm{C}$ for 10 seconds, annealing at $59^{\circ} \mathrm{C}$ for 10 seconds with data acquisition and extension at $72^{\circ} \mathrm{C}$ for 32 seconds. Data analysis was performed at channel F2.

\section{PCR}

PCR was performed for amplification of herpes simplex viruses type 1 and type 2 (HSV-1, HSV-2), Varicella Zoster virus (VZV), Epstein Barr virus (EBV), cytomegalovirus (CMV) and human herpes virus type 6 (HHV-6) DNAs using the Herpes Consensus Generic kit (Argene, Verniolle, France). The primers sets were targeted to a conserved region in the DNA polymerase gene of these herpesviruses. DNA was amplified and detected alternately according to the manufacturer's instructions.

\section{Real-time PCR}

Real-time PCR was performed to detect HSV-1 and HSV-2 in the AITD patients' biopsies using a LightCycler HSV 1/2 Detection kit (Roche
Diagnostics, Penzberg, Germany) according to the manufacturer's instructions.

\section{Serological tests}

Anti-TPO and anti-TG antibodies titers were measured in the serum of all 100 subjects using the Liaison Anti-TPO kit (DiaSorin, Saluggia, Italy) for anti-TPO assay with normal values ranging from 0 $16 \mathrm{unit} / \mathrm{ml}$ and the Liaison Anti-Tg kit (Diasorin, Italy) for anti-TG assay with normal values ranging from 5-100 units $/ \mathrm{ml}$ according to the manufacturer's instructions.

\section{Statistical study}

Significant differences were assessed by the Sign test and a $\mathrm{P}$ value $<0.05$ was considered significant.

\section{Results}

Quality of DNA

Absorbance at $260 \mathrm{~nm}$ of extracted DNA of all tested samples measured between $70-500 \mathrm{ng} / \mu \mathrm{l}$, and 260/280 ratios ranged from 1.7 to 1.9. Amplified beta globin gene was detected in all investigated samples.

\section{Detection of herpes viruses genome by PCR}

The DNA of HSV-1, HSV-2, VZV, EBV, CMV and HHV-6 were undetectable in all 100 samples.

Amplification of HSV-1 and HSV-2 by real-time PCR

The DNA of HSV-1 and HSV-2 were undetectable in all 50 specimens of AITD patients.

\section{Serological tests}

The mean value of anti-TPO antibodies ranged from 9.5 to 2000 units/ml $(527.8 \pm 617.4)$ in the AITD group, and 0 to 26 units $/ \mathrm{ml}(4.84 \pm 5.14)$ in the control group. The mean value of anti-TG antibodies ranged from 108-5000 units/ml $(1458.2 \pm 1774.1)$ in the AITD patients group, and ranged from 5-102 units/ml (13.4 \pm 16.7) in the control group. Statistically significant differences in the mean values of anti-TPO antibodies and anti-TG antibodies were found between the two groups $(\mathrm{P}=0.000)$.

Anti-TPO antibodies were positive in 39 out of $50(78 \%)$ AITD patients compared to 3 out of 50 (6\%) non-autoimmune thyroid disease (MNG) patients. Anti-TG antibodies were positive in 28 out of $50(56 \%)$ AITD patients compared to 2 out of 50 (4\%) MNG patients. 


\section{Discussion}

Our findings of undetectable herpes viruses DNA in thyroid specimens are inconsistent with the study of Thomas et al. [12] who reported the detection of HSV in 13 out of 18 (72.22\%) in their patient group and in 1 of $4(25 \%)$ in their control group. This might be due to the different geographical regions in which the studies were conducted as HSV seroprevalence has varied significantly accordingly [13].

Thomas's study included DNA extraction from paraffin embedded tissue sections, and the amplified product was detected by gel electrophoresis. In our study, however, DNA was extracted from freshly frozen tissue from which fresh biopsies are better digested and yield good quality DNA [14], and the amplified product was detected by ELISA as an established quantitative and qualitative method (PCR detection limit was 20 DNA copies/reaction).

Positivity of beta globin real time PCR in all our tested samples assured the absence of PCR inhibitors in our DNA extracts. It is not known if HSV-1, HSV2, VZV, EBV, CMV and HHV-6 have the tropism to the thyroid gland, and if they are capable of persisting in the thyroid gland after primary infection [12], which might explain undetectable herpes virus DNA in our samples. However, these samples were obtained from one site of a biopsy which does not represent whole thyroid.

Our findings of anti-TPO and anti-TG antibodies in AITD patients are consistent with those of Elmugadam et al. [15] who detected 15 out of 21 (71.4\%) positive anti-TPO antibodies and 7 out of 21 (33.3\%) positive anti-TG antibodies, in their AITD patients. On the contrary, anti-TPO and anti-TG antibodies findings in their control group were not in accordance with our findings. This discrepancy might be due to the difference of inclusion criteria of their control group, which was divided into two groups (hyperthyroidism patients and hypothyroidism patients) while our control group generally consisted of MNG patients.

\section{Conclusion}

Our raised question stays open for more investigation on more patients and in different parts of the country, using different sizes and sites of biopsies.

\section{References}

1. Weetman AP (2003) Autoimmune thyroid disease: propagation and progression. Eur J Endocrinol 148: 1-9.
2. Swain M, Swain T, Mohanty BK. Autoimmune thyroid disorders: an update (2005) Indian Journal of Clinical Biochemistry 20: 9-17.

3. Aleksić Z, Aleksić A, Mitov V, Jović M ,Zdravović D (2008) Amiodarone treatment and thyroid autoimmunity markers. Hell J Nucl Med 11: 105-109.

4. Schott M and Scherbaum W (2006) Autoimmune thyroid disease. Dtsch Arztebl 103: A 3023-3032.

5. Dayan CM and Daniels GH (1996) Chronic autoimmune thyroiditis. N Engl J Med 335: 99-107.

6. Raghunath B, Pratim SP, Kumar GT, Amitabha M, Subhankar C, Shyamal D (2009) Postpartum thyroid dysfunction: Is there any relation with antepartum serum Thyroid Peroxidase (TPO) antibody status? J Obstet Gynecol India 59: 156-159.

7. Padgett DA and Sheridan FS (2000) Herpesviruses. In Fink G, editor. Encyclopedia of stress, Vol 2. San Diego, CA: Academic Press. 357-363.

8. Raborn GW and Grace MG (2003) Recurrent herpes simplex labialis: selected therapeutic options. J Can Dent Assoc 69: 498-503.

9. Posnett DN (2008) Herpesviruses and autoimmunity. Curr Opin Investig Drugs 9: 505-514.

10. Tadmouri GO (1999) $\beta$-Thalassemia in Turkey: distribution, diversity, evolution and phenotype-genotype correlations. $\mathrm{PhD}$ thesis. Boðaziçi University.

11. Moreno I, Bolufer P, Perez ML, Barragán E, Sanz MA (2002) Rapid detection of the major Mediterranean betathalassaemia mutations by real-time polymerase chain reaction using fluorophore-labelled hybridization probes. $\mathrm{Br}$ J Haematol 119: 554-557.

12. Thomas D, Liakos V, Michou V, Kapranos N, Kaltsas G, Tsilivakos V (2008) Detection of herpes virus DNA in postoperative thyroid tissue specimens of patients with autoimmune thyroid disease. Exp Clin Endocrinol Diabetes 116: 35-39.

13. Pebody RG, Andrews N, Brown D, Gopal R, De Melker H, François G, Gatcheva N, Hellenbrand W, Jokinen S, Klavs I, Kojouharova M, Kortbeek T, Kriz B, Prosenc K, Roubalova K, Teocharov P, Thierfelder W, Valle M, Van Damme P, Vranckx R (2004) The seroepidemiology of herpes simplex virus type 1 and 2 in Europe. Sex Transm Infect 80: 185191.

14. Talauilikar D, Gray JX, Shadbolt B, McNiven M, Dahlstrom JE (2008) A comparative study of the quality of DNA obtained from fresh frozen and formalin-fixed decalcified paraffin-embedded bone marrow trephine biopsy specimens using two different methods. J Clin Pathol 61: 119-123.

15. Elmugadam AA, Elobied EA, Elebaid MH, Makeen AM (2010) Prevalence of anti-thyroid peroxidase, and antithyroglobulin in Sudanese patients with thyroid diseases. Egypt Acad J Biolog Sci 2: 93-97.

\section{Corresponding author}

Noura AL-Zarzour

Faculty of Pharmacy

Damascus University

Damascus, Syria

Telephone: +963-932611134

Fax: +963-11-2139441

Email: noura_zarzour@hotmail.com

Conflict of interests: No conflict of interests is declared 